Таким образом, исследование антропонимической лексики неотделимо от изучения внеязыковой действительности. Комплексное изучение подобных языковых явлений помогает глубже понять духовную сущность, мировоззрение, иерархию ценностей того или иного народа.

1. Щетинин Л.М. Слова, имена, вещи. - Ростов н/Д.: Издательство Ростовского университета, 1972. $231 \mathrm{c}$.

2. Томахин Г.Д. Реалии-американизмы. Пособие по страноведению: Учеб. пособие для ин-тов и фак. иностр. яз. - М.: Высшая школа, 1988. - 239 с.

3. https://translate.academic.ru/

4. https://www.theguardian.com/uk-news/2016/jul/09/

5. https://nytimes.com/2020/05/09/

\title{
Kulmagambetova S.S., Shalabayeva A.A. Using of modern educational technologies in teaching English for high school
}

Professor M.Utemisov WKU (Kazakhstan, Uralsk)

doi: $10.18411 / \mathrm{lj}-06-2021-140$

\section{Abstract}

The article analyzes the feasibility of introducing modern information and computer technologies, multimedia tools, and advanced techniques in the process of mastering a foreign language. The necessity of using innovative technologies in the practice of teaching foreign languages is analyzed.

Keywords: computer, information technology, Internet, English, multimedia.

\section{Аннотация}

В статье анализируется целесообразность внедрения современных информационных и компьютерных технологий, мультимедийных средств и передовых методик в процесс овладения иностранным языком. Анализируется необходимость использования инновационных технологий в практике преподавания иностранных языков.

Ключевые слова: компьютер, информационные технологии, Интернет, английский язык, мультимедиа.

The rapid and radical changes taking place in modern society, advances in the theory and practice of learning English make the education system need to update the content and methods of using innovative technologies in foreign language teaching.

Education must meet modern needs and realities, use not only the experience and experience of past years but also implement modern technologies, develop relevant teaching methods and techniques. "In a globalized world, methods of learning and teaching foreign languages must be better adapted to the ever-changing needs and conditions of language learners. New technologies open up huge opportunities for enhanced individualization of learning" [4].

Like all areas, education must develop and keep pace with transformations and metamorphoses in society.

Teaching approaches and methods are being modernized with the emergence of new opportunities. Today the educational process in the country's educational institutions is being reformed by global requirements for the quality of education: informatization of the educational space, integration processes in modern domestic education, establishing 
cooperation with foreign educational institutions in the field of education and research, international exchanges and more.

The use of modern information technologies in lessons is an extremely important and at the same time problematic issue for a foreign language teacher. In the methodology of teaching foreign languages, this problem has been developed since the early ' 80 s of the twentieth century. Today, the use of information technology is one of the conditions for successful foreign language learning. Therefore, a foreign language teacher must, in addition to thorough professional training, mastery of modern communication techniques, use information technology at all stages of learning - it is a matter of time. Modern information technologies should be an effective tool that will facilitate the acquisition of knowledge, make learning interactive, communicative, interesting, visual, individual.

The use of cyberspace for educational purposes is a completely new direction of general didactics, as the changes taking place cover all aspects of the educational process, from the choice of techniques and style of work to changing the requirements for the academic level of students. The purpose of our article is to consider the possibilities of using modern technologies in teaching foreign languages.

Modern technologies in education are professionally-oriented foreign language teaching, project work in teaching, application of information and telecommunication technologies, work with educational computer programs in foreign languages (multimedia system), distance technologies in foreign language teaching, creation of presentations in the program. PowerPoint, use of Internet resources, learning a foreign language in a computer environment (forums, blogs, e-mail), the latest test technologies (creating a bank of diagnostic materials for the course "Foreign language" for computer testing) [1].

The substantive basis of mass computerization of education is certainly because the modern computer is an effective means of optimizing the conditions of mental work in general, in any of its manifestations.

The World Wide Web allows you to go on a virtual tour around the world, take part in international competitions and Olympiads, organize and conduct joint telecommunications projects, thematic presentations, communicate in text and voice chats. Especially the generation of Internet users expects that the devices and forms of communication that they use in everyday life will be useful in the field of language learning. They make language learners independent in space and time and facilitate conscious, autonomous, constructive language learning. A certain psychological barrier, insecurity, and lack of contact with the teacher can be leveled by the involvement of computer technology in the learning process.

The presence of artificial intelligence in the process of mastering a foreign language allows you to study remotely and independently, provides an opportunity to tune in to the most effective perception, gives a sense of control over the situation and being in the comfort zone. In addition, the Internet is an inexhaustible resource for the teacher in preparation for the lesson, the introduction of vocabulary on any topic, the introduction of new types of speech activities.

As an information system, the Internet offers its users a variety of information and resources. The basic set of services may include e-mail, teleconferencing, videoconferencing, the ability to publish their research papers on educational sites and receive feedback from them around the world, create your home page and place it on a Web server, access to information resources: reference directories (Yahoo!, InfoSeek / UltraSmart, LookSmart, Galaxy) and search engines (Alta Vista, HotBob, Open Text, WebCrawler, Excite) [5].

The basis of the World Wide Web is communication, which provides direct communication with native speakers through correspondence with peers from other countries, creating and conducting joint telecommunications projects, participating in text and voice chats, reading hypertext information, using online dictionaries, and much more. The Internet also provides an opportunity to communicate with foreign peers in a virtual form. 
The huge popularity of social networks and websites has created new opportunities for mastering the English language. Advances in technology mean that today, pupils and students can easily communicate with other members of the learning process in a practice that promotes language acquisition, communicative competence, and motivation. With the advent of social networking sites, streaming video, blogs, podcasts, and wikis, today's capabilities can be considered revolutionary, where technology lies at the heart [3].

The introduction of computer technology teaches students to work independently, solve problems and respond to the challenges they face, stimulates self-education throughout life. As a result of the scientific and technological revolution, there is a need for continuing education: knowledge is aging so fast that we have to constantly retrain. Accordingly, the ability to learn becomes one of the most important skills. And it is this skill that is acquired when learning a foreign language with the help of computer technology [1].

The methodological advantages of teaching a foreign language with the help of multimedia tools show that this method has a greater degree of interactive learning, allows you to choose the pace and level of tasks, improves the speed of learning grammar and vocabulary. Also, the undoubted technical advantages of this method include the ability to use interactive video and audio clips in teaching oral speech. Demonstrating diagrams, photos, and drawings on the subject of language communication, the principle of clarity is realized. The introduction of multimedia technologies creates conditions for interactive communication, which today is the most important component of the educational process. Using multimedia technologies, the teacher can present information in a completely new and effective form, make it more complete, interesting, and close to the subject of communication being studied.

Multimedia tools allow you to use almost all the senses of students, combining printed text, graphics, moving video, still photos, and audio, creating a "virtual reality" of real communication. It is proved that the use of multimedia materials and computer networks reduces learning time by almost three times, and the level of memorization through the simultaneous use of images, sound, text increases by 30-40 percent [2].

G. V. Romanova offers various ways to use multimedia tools in the educational process, including the use of electronic lecturers, simulators, textbooks, encyclopedias, development of situational role-playing and intellectual games using artificial intelligence, modeling processes and phenomena, providing distance learning, building control systems and testing of knowledge and skills of pupils and students (use of controlling programmers), creation and support of sites of educational institutions, creation of presentations of educational material, the realization of projective and research activity of pupils, etc. [4].

Also, multimedia technologies allow you to develop brighter and more interesting speaking exercises. For students, learning a foreign language using multimedia technology also has certain advantages. Since these technologies are new, it is interesting for students to deal with sources of new types of information. And it is also important that the assimilation of new information using multimedia technologies takes place in the form of games. The use of multimedia technologies allows students to independently prepare mini-projects on the subject of communication and present them. When mastering a foreign language, students have several problems, one of which is low motivation to learn the language. In such cases, it is interactive technologies that are valuable for application, because they create such conditions when the student feels his success and intellectual ability. Effective collaboration and communication are basic components of such training, which aims to solve problems together, acquire monologue skills, responsibility, critical thinking, and achieve meaningful results.

At the present stage in our country, the use of automated training courses for learning foreign languages is spreading. But they should be used only as an aid in teaching a foreign language. It is especially useful to use them at the stage of acquainting pupils and students with new language material, new samples, as well as at the stage of training. Students have 
the opportunity to train to spell, study lexical material, improve understanding of the audio text, develop reading techniques, learn grammar, train pronunciation [2].

Thus, at the present stage of development of science we can say for sure that the times when sufficient proof of language acquisition was the ability to translate from a foreign language and, conversely, adapted, non-authentic texts are over. In the context of high school reform, educational technologies for teaching foreign languages must also change. Involvement of modern technologies in the process of learning a foreign language significantly expands and diversifies the program, provides access to a variety of materials, expands students' motivation to learn, allowing them to work on the language at a pace convenient for them, thus individualizing learning and mastering a foreign language.

$* * *$

1. Chilingaryan, M. V. (2016) Ispol'zovaniye informatsionno-obrazovatel'nykh tekhnologiy na urokakh angliyskogo yazyka // Nauchno-metodicheskiy elektronnyy zhurnal «Kontsept». № S12. URL: http://ekoncept.ru/2016/76148.htm.

2. Hutchinson T., Waters A. English for Specific Purposes: A learning-centred approach. - Cambridge: Cambridge University Press, 2009. - 183 p.

3. Rieger, Caroline R. How (not) to be rude: Facilitating the acquisition of L2 (im)politeness // Intercultural Pragmatics. 2018. V. 15. Issue 5. Pp. 651-691

4. Romanova, G. V. (2016) Razvitiye inoyazychnoy grammaticheskoy kompetentsii obuchayushchikhsya 9kh klassov s uchetom ikh psikhologo-vozrastnykh i individual'nykh osobennostey (na osnove primeneniya interaktivnoy doski) // Pedagogicheskoye obrazovaniye v Rossii. № 2. S. 189-194.

5. Tsifrovaya transformatsiya obrazovaniya: sb. mat. 2-y Mezhd. nauch.-prakt. konf., Minsk, 27 marta 2019 g. / otv. red. A. B. Bel'skiy. - Minsk: GIATS Minobrazovaniya, 2019. - Rezhim dostupa: http://dtconf.unibel.by/doc/Conference_2019.pdf

\section{Vorontsova U.A.}

Forming and translating English neologisms in the software engineering field

Bryansk State Technical University

(Russia, Bryansk)

doi: $10.18411 / \mathrm{j}-06-2021-141$

\section{Abstract}

The article is devoted to defining the peculiarities and focus of translating English neologisms in the software engineering terminology. As part of the study the role of vocabulary is explored, the features of neologism derivations are classified; the main methods of their interpreting into Russian are examined, the ways of neologism word-building in the software engineering terminology are identified and the most frequent interlingual transformations used in conveying their meaning into Russian are determined. Results of the study reveal that the majority of neologisms are formed predominantly by stem-composition and affixation and the most common method of translating neologisms in the software engineering terminology is the loan-translation, transcription and translation method, grammatical substitutions and descriptive translation.

Keywords: software engineering, neologisms, translation transformations, translation, word-building.

\section{Аннотация}

Статья посвящена определению особенностей и направленности перевода английских неологизмов в терминологии программной инженерии. $\mathrm{B}$ статье проясняется роль лексики, анализируются особенности создания неологизмов, выделяются основные способы их передачи на русский язык, выявляются способы словообразования неологизмов в терминологии программной инженерии и определяются наиболее частотные переводческие трансформации, использованные при 